\title{
Occurrence and sources of brominated and organophosphorus flame retardants in dust from different indoor environments in Barcelona, Spain
}

\author{
Joyce Cristale ${ }^{*, 1}$, Alba Hurtado, Cristian Gómez-Canela, Silvia Lacorte \\ Department of Environmental Chemistry, IDAEA-CSIC, Jordi Girona 18-26, 08034 Barcelona, Catalonia, Spain
}

\section{A R T I C L E I N F O}

\section{Article history:}

Received 28 January 2016

Received in revised form

1 May 2016

Accepted 2 May 2016

Available online 11 May 2016

Keywords:

Indoor dust

Novel brominated flame retardants

Organophosphate esters

PBDE

Distribution pattern

\begin{abstract}
A B S T R A C T
In this study, the simultaneous presence of eight polybrominated diphenyl ethers (PBDEs), nine new brominated flame retardants (NBFRs) and ten organophosphorus flame retardants (OPFRs) was investigated in dust samples collected from different indoor environments (homes, schools, theatres, a university and a Research Institute) in Barcelona, Spain. OPFRs were detected at the highest concentrations followed by PBDEs. $\Sigma$ OPFRs ranged from 2053 to $72,090 \mathrm{ng} \mathrm{g}^{-1}$ and tris(2-chloroisopropyl) phosphate (TCIPP) was the most abundant compound. BDE-209 was the main PBDE congener detected (up to $14,990 \mathrm{ng} \mathrm{g}^{-1}$ ), while other PBDEs ranged from 2.6 to $118 \mathrm{ng} \mathrm{g}^{-1}$. Among the studied NBFRs, decabromodiphenyl ethane (DBDPE - up to $4432 \mathrm{ng} \mathrm{g}^{-1}$ ) followed by bis(2-ethylhexyl) tetrabromophthalate (BEH-TEBP - up to $508 \mathrm{ng} \mathrm{g}^{-1}$ ) were detected at the highest concentration, whereas a lower detection frequency was observed for 2-ethylhexyl 2,3,4,5-tetrabromobenzoate (EH-TBB), 1,2-bis (2,4,6-tribromophenoxy)ethane (BTBPE), pentabromotoluene (PBT) and hexabromobenzene (HBB). The levels and profile of flame retardants (FRs) were characteristic of each environment, where theatres followed by homes presented the highest concentrations and schools had the lowest levels. Principal Component Analysis permitted to identify the main sources and distribution of all FRs, according to specific uses in each environment. The simultaneous presence of all FR families in indoor dust points to the need to monitor these compounds to minimize human exposure.
\end{abstract}

(c) 2016 Elsevier Inc. All rights reserved.

\section{Introduction}

Flame retardants (FRs) are a group of chemicals applied to different materials to reach fire safety standards adopted by many countries (BSI, 1982; OJEC, 1995, 2000). Several organic and inorganic compounds based on bromine (e. g. high brominated aromatic and cycloaliphatic compounds), chlorine (e.g. chloroparaffins, declorane plus), phosphorus (e. g. phosphate-esters, phosphonates and phosphinates, ammonium phosphate), nitrogen (e. g. melamine and melamine derivatives), boron (e.g. sodium borate, borax and zinc borates), and metallic hydroxides are used for this purpose (SpecialChem, 2013). The choice of the appropriate flame retardant, or combination of them, is dependent of the type material and the desired performance for the final product.

\footnotetext{
* Corresponding author.

1 Present address: Department of Analytical Chemistry, Institute of Chemistry, UNESP - Univ Estadual Paulista, Professor Francisco Degni 55, 14800-060, Araraquara (SP), Brazil.
}

Some families of FRs that were used in the past or that are nowadays in use are of concern because of their toxicity to humans and to the environment. Flame retardant formulations containing polybrominated diphenyl ethers (PBDEs) were extensively applied to textiles, furniture, electronic and building materials after 1970s (Alaee et al., 2003). PBDEs present high bioaccumulation potential, are endocrine disruptors and neurotoxicants (Darnerud, 2003; Vonderheide et al., 2008; WHO, 1994) and these characteristics lead to their restriction/ban in Europe (ECJ, 2008; OJEU, 2003a, 2003b, 2005). Due to these bans, other organic flame retardants have been used as PBDE substitutes, such as new brominated flame retardants (NBFRs) and organophosphorus flame retardants (OPFRs) (Covaci et al., 2011; van der Veen and de Boer, 2012), but the safety of these compounds to humans and to the environment still needs to be elucidated. Some NBFRs are structurally similar to PBDEs indicating that these chemicals have a potential for bioaccumulation and toxicity (Ezechiáš et al., 2014). On the other hand, OPFRs may pose a risk to humans, for instance tris(2-chloroethyl) phosphate (TCEP) is classified as carcinogen (category 3) (ECHA, 2008) and tris(1,3-dichloropropyl) 
phosphate (TDCIPP) was carcinogenic at all exposure doses that were tested in rats (WHO, 1998). Thus, although the use of FRs are advantageous when considering the decreasing death and injuries associated to fires (EFRA, 2005), there is a concern regarding the exposition to these substances due to the potential toxicity that some FRs pose to humans and to the environment.

Many flame retardants are additives (not chemically bound) and thus they are released from the host materials throughout their lifetime to the surrounding environment due to volatilization and mechanical abrasion, tending to accumulate in dust particles (Liagkouridis et al., 2014; Rauert et al., 2014). The materials commonly found at homes, schools, workplaces and public places that are potential sources of OPFRs, NBFRs and PBDEs include: (i) rigid polyurethane (PU) foam - used in insulation, construction and refrigeration; (ii) flexible PU foam - used in furniture and upholstery; (iii) textiles; (iv) acrylonitrile-butadiene-styrene (ABS) and high impact polystyrene (HIPS) typically used in enclosures of electric and electronic equipments (EEE), such as computers, printers, TVs, etc.; (v) polyethylene and polyvinyl chloride (PVC), used in wiring and cables and cable jacketing; (vi) polypropylene used in cable conduit, power cables, connectors, seats, fibers (carpets, seats, etc.); (vii) polyamides used in medium voltage components, insulation, switch casings, plug connectors, terminal blocks, etc. (SpecialChem, 2013). Consequently, mixtures of flame retardants of different families are found in dust samples from indoor environments, such as homes, offices, schools and workplaces (Ali et al., 2012; Mizouchi et al., 2015; Stapleton et al., 2009).

Non-intentional ingestion of dust particles and dermal absorption was indicated as a significant human exposure route to FRs (Kim et al., 2013; Lim et al., 2014; Abdallah et al., 2015). This exposure pathway is of special concern for toddlers since their more frequent hand-to-mouth contact and close-to-ground behaviour could lead to higher amount of dust ingestion, and their lower body weigh results in a higher daily exposure. Some brominated FRs have potential to affect endocrine functions and the central nervous and reproductive systems (Lyche et al., 2015). Concerning the OPFRs, their presence in floor dust was suggested to be associated with the prevalence of asthma, atopic dermatitis and allergic rhinitis (Araki et al., 2014). Thus, studies on the occurrence of different flame retardant families in indoor dust are necessary given that these chemicals can pose a threat to human health. The aim of this work was to evaluate the co-occurrence of PBDEs, NBFRs and OPFRs in dust samples collected in homes and public places (schools, theatres and research institute/university) in Barcelona in order to identify specific compound profiles and sources of these compounds in each indoor environment.

\section{Materials and methods}

\subsection{Chemicals}

A PBDE mix (BDEs 28, 47, 99, 100, 153, 154, 183 and 209) in $n$ nonane at $1 \mu \mathrm{g} \mathrm{mL}^{-1}$ was acquired from Cambridge Isotope Laboratories (Andover, USA). Individual solution of 1,2-bis(2,4,6-tribromophenoxy)ethane (BTBPE) at $50 \mu \mathrm{g} \mathrm{mL}^{-1}$ in $5 \%$ toluene in nonane, decabromodiphenyl ethane (DBDPE) at $25 \mu \mathrm{g} \mathrm{mL}^{-1}$ in toluene, bis(2-ethylhexyl) tetrabromophthalate (BEH-TEBP), pentabromotoluene (PBT), 2,4,6-tribromophenyl 2,3-dibromopropyl ether (TBP-DBPE), 5,6-dibromo-1,10,11,12,13,13-hexachloro-11-tricyclo[8.2.1.02,9]tridecene (DBHCTD) and 2-ethylhexyl 2,3,4,5-tetrabromobenzoate (EH-TBB) (at $50 \mu \mathrm{g} \mathrm{mL}^{-1}$ in toluene) were acquired from Wellington Laboratories (Guelph, Canada). Hexabromobenzene (HBB), pentabromoethylbenzene (PBEB), tris(2choroethyl) phosphate (TCEP), tris(2-chloroisopropyl) phosphate
(TCIPP), tris(1,3-dichloroisopropyl) phosphate (TDCIPP), tris(phenyl) phosphate (TPHP), 2-ethylhexyl diphenyl phosphate (EHDPHP) and tris(butyl) phosphate (TNBP) were acquired from Sigma Aldrich (Germany). TCIPP was acquired as a mixture of isomers (tris(2-chloroisopropyl) phosphate, bis(1-chloro-2-propyl)-2-chloropropyl phosphate, and bis(2-chloropropyl)-1-chloro2-propyl phosphate). Tris(2-butoxyethyl) phosphate (TBOEP), tris (2-ethylhexyl) phosphate (TEHP) and tris(methylphenyl) phosphate (TMPP) were acquired from Dr. Ehrenstorfer (Augsburg, Germany). Tris(isobutyl) phosphate (TIBP) at $1000 \mu \mathrm{g} \mathrm{mL}^{-1}$ was acquired from Chiron (Trondheim, Norway). The surrogates $\left.{ }^{13} \mathrm{C}_{6}\right]$ hexabromobenzene (MHBB) at $50 \mu \mathrm{g} \mathrm{mL}^{-1}$ in toluene, $3,3^{\prime}, 4,4^{\prime}$-tetrabromo $\left[{ }^{13} \mathrm{C}_{12}\right.$ ]diphenyl ether (MBDE-77) at $50 \mu \mathrm{g} \mathrm{mL}{ }^{-1}$ in nonane and decabromo $\left[{ }^{13} \mathrm{C}_{12}\right.$ ]diphenyl ether (MBDE-209) at $25 \mu \mathrm{g} \mathrm{mL}^{-1}$ in toluene, were acquired from Wellington Laboratories (Guelph, Canada). Tris(phenyl) phosphate-D15 (TPHP-D15) was acquired from Sigma Aldrich (Germany). Tris (butyl) phosphate-D27 (TNBP-D27) was acquired from Cambridge Isotope Laboratories (Andover, USA). The internal standards 2,3,5,6-tetrachlorobiphenyl (PCB-65) and decachlorobiphenyl (PCB-209), both at $10 \mu \mathrm{g} \mathrm{mL}^{-1}$ in iso-octane, were acquired from Dr. Ehrenstorfer (Augsburg, Germany). Ethyl acetate and toluene were acquired from Merck (Darmstadt, Germany). Cyclohexane was acquired from Scharlau (Sentmenat, Spain). Florisil cartridges were acquired from Waters $(5 \mathrm{~g}, 20 \mathrm{cc})$.

\subsection{Sampling}

Dust samples were collected in Barcelona (Spain) from five homes, four schools, three theatres, one research institute and one university. The characteristics of each are given in Table 1. Vacuum cleaner bag from the apparatus used for vacuuming in each particular environment was provided by the responsible person in each sampling place. The accumulated dust was carefully removed from vacuum cleaner bag, sieved $(500 \mu \mathrm{m})$ and stored at $-18{ }^{\circ} \mathrm{C}$ until analysis. When necessary, hair and other strange materials were manually removed using tweezers.

\subsection{Extraction and analysis}

Extraction was performed as described elsewhere (Cristale and Lacorte, 2013). Briefly, $0.1 \mathrm{~g}$ of dust was spiked with the surrogate standards and extracted with $10 \mathrm{~mL}$ of ethyl acetate/cyclohexane $(5: 2 \mathrm{v} / \mathrm{v})$ in an ultrasonic bath $(10 \mathrm{~min})$ (three times). The extract was concentrated to $1 \mathrm{~mL}$ under $\mathrm{N}_{2}$ flow in a Turbovap, and subjected to clean-up using Florisil cartridges. Cartridges were conditioned with $30 \mathrm{~mL}$ of ethyl acetate/cyclohexane $(5: 2 \mathrm{v} / \mathrm{v})$ and after placing the extract on top of the cartridge, compounds were eluted with $30 \mathrm{~mL}$ of the same solvent mixture, then the solvent was concentrated under $\mathrm{N}_{2}$ flow to almost dryness and reconstituted in toluene containing the internal standards PCB-65 and PCB-209 at $0.05 \mu \mathrm{g} \mathrm{mL}^{-1}$. Six procedural blanks were extracted and analyzed together with the samples. OPFRs in procedural blanks were detected at concentrations from 0.2 to $14 \%$ of the observed OPFR concentrations in dust samples, and no correction considering blank contribution was done. Details concerning limits of detection of the method (MDL) and extraction efficiency were described in that previous study (Cristale and Lacorte, 2013). In short, MDL ranged from 2.0 to $275 \mathrm{ng} \mathrm{g}^{-1}$ for PBDEs, from 5.0 to $237 \mathrm{ng} \mathrm{g}^{-1}$ for NBFRs and from 3.8 to $288 \mathrm{ng} \mathrm{g}^{-1}$ for OPFRs. TBOEP had an error of $-80 \pm 3 \%$ in relation to the assigned OPFRs levels for the reference material SRM 2585 - NIST (house dust), as observed by participating in an interlaboratory study (Cristale and Lacorte, 2013). Given the low recovery of TBOEP, its presence is reported in this study as semi quantitative levels.

Extracts were analyzed by GC-EI-MS/MS in a GC Agilent 7890 A 
Table 1

Information on the sites monitored and their specific characteristics.

\begin{tabular}{|c|c|c|c|c|}
\hline Site & Characteristics & Capacity & Year & Usage \\
\hline \multicolumn{5}{|l|}{ Theatres } \\
\hline T1 & Wooden floor and carpet, curtains & 357 seats & $\begin{array}{l}1949-2010 \text { was a cinema and } \\
\text { since } 2010 \text {, a theatre. }\end{array}$ & Open from Thursday to Sunday, 12 plays/week \\
\hline T2 & All surfaces with carpet & 329 seats & $\begin{array}{l}\text { Cinema, closed, rebuilt and reo- } \\
\text { pened as theatre in } 2010 .\end{array}$ & $\begin{array}{l}\text { Samples collected after the } 1 \text { st cleaning before inaugura- } \\
\text { tion. Open from Thursday to Sunday, } 5 / 6 \text { plays/week }\end{array}$ \\
\hline T3 & Wooden floor, no curtains & 362 seats & 1998 & $\begin{array}{l}\text { Open from Wednesday till Sunday. (average of } 9 / 10 \text { plays/ } \\
\text { week) }\end{array}$ \\
\hline \multicolumn{5}{|r|}{ 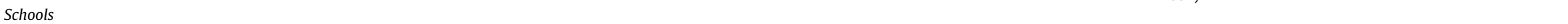 } \\
\hline S1 (secondary school) & Tiles, curtains, chalk board, wooden chairs and tables. & aprox. $3000 \mathrm{~m}^{2}$ & 1862 & 800 children aged $3-18$ years. \\
\hline S2 (Primary school) & Tiles, no curtains, PC, chalk board, digital board, wooden chairs and tables & $2926 \mathrm{~m}^{2}$ & 1961 & 600 children aged $6-12$ years. \\
\hline S3 (Kindergarten) & Tiles, curtains, PC, chalk board, toys, mattresses, wooden chairs and tables. & $1640 \mathrm{~m}^{2}$ & 1961 & 360 children aged $2-5$ years. \\
\hline S4 (Primary school) & Tiles, curtains, chalk board, wooden chairs and tables. & aprox. $2000 \mathrm{~m}^{2}$ & 1970 & 500 children aged $2-13$ years. \\
\hline \multicolumn{5}{|l|}{ Research institutions } \\
\hline $\mathrm{U}$ & Classrooms and halls & $500 \mathrm{~m}^{2}$ & Operating since 1960 & 20-100 people \\
\hline RI & Mass Spectrometry Laboratory, analytical instruments & $250 \mathrm{~m}^{2}$ & Operating since 2007 & 10 people \\
\hline \multicolumn{5}{|c|}{ 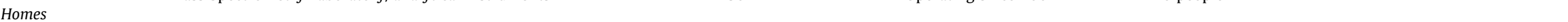 } \\
\hline H1 & Tiles, furniture, no curtains, TV, 3 laptops & $\begin{array}{l}100 \mathrm{~m}^{2}, 6 \text { th floor, center } \\
\text { of BCN }\end{array}$ & Old house* & 3 adults living \\
\hline H2 & Wooden floor, old furniture, new TV and 2 laptops & $\begin{array}{l}85 \mathrm{~m}^{2}, 3 \text { rd floor, St. } \\
\text { Gervasi }\end{array}$ & Old house* & 2 adults living (one of them allergic to dust) \\
\hline H3 & Wooden floor, carpet in living room, new furniture, curtains, TV, 2 laptops. & $\begin{array}{l}32 \mathrm{~m}^{2}, 4 \text { th floor, } \\
\text { L'Hospitalet }\end{array}$ & New house & 2 adults living (one of them allergic to dust) \\
\hline H4 & $\begin{array}{l}\text { Wooden floor, old furniture, cotton curtains, no TV, } 5 \text { computers and a lot of } \\
\text { electronic devices and cables related to the work of one of its dwellers. }\end{array}$ & $112 \mathrm{~m}^{2}, 4$ th floor, Sarrià. & Old house* & 2 adults, 3 teenagers living \\
\hline H5 & Wooden floor and carpet, very old furniture, curtains, TV, 1 computer. & $\begin{array}{l}250 \mathrm{~m}^{2}, 1 \text { st floor, St. } \\
\text { Gervasi }\end{array}$ & Old house* & 2 adults living \\
\hline
\end{tabular}

* Old house means a building of more than 30 years. 

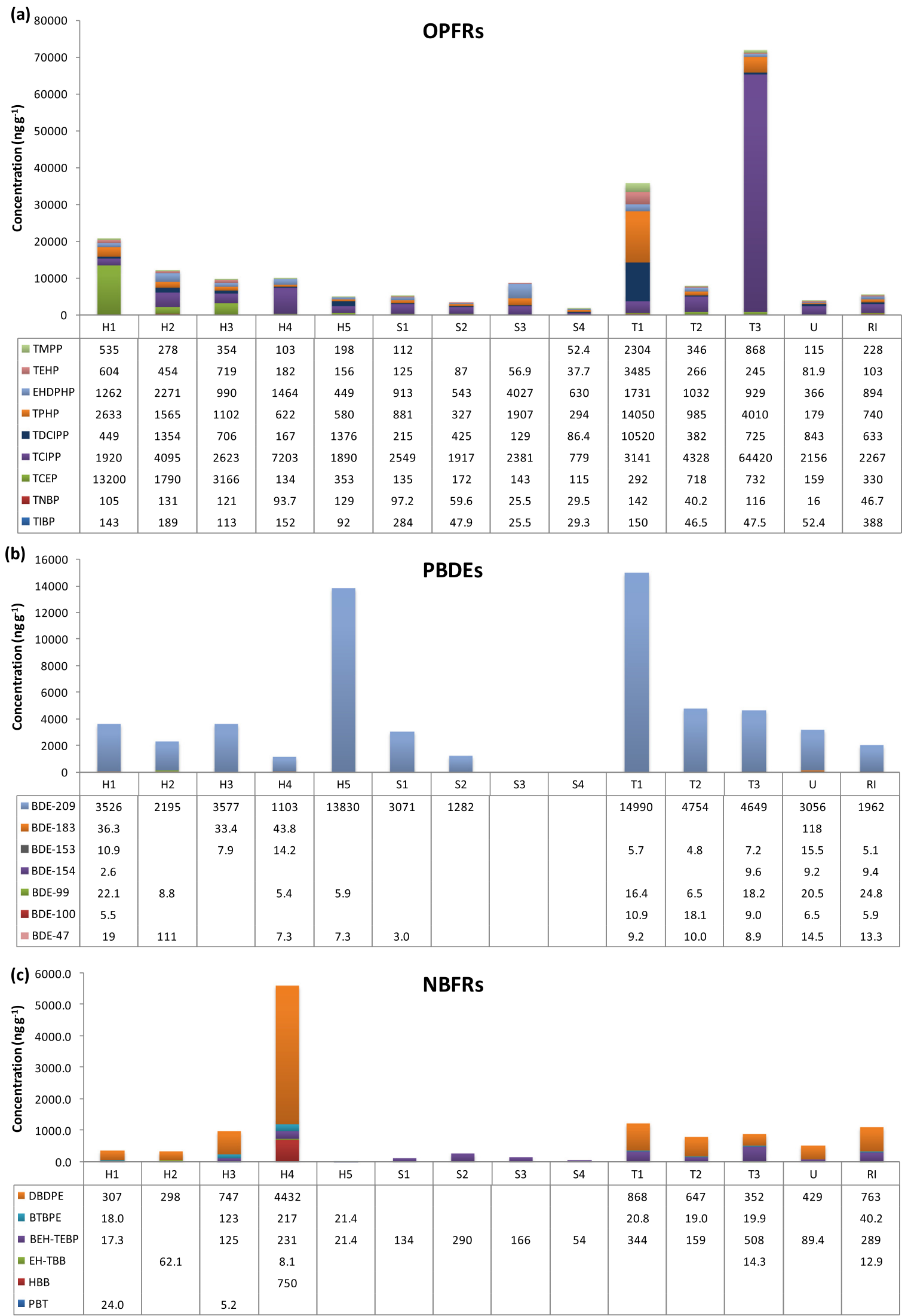

Fig. 1. Concentration of target FRs in dust samples $\left(\mathrm{ng} \mathrm{g}^{-1}\right)$ collected in homes (H1-5), Schools (S1-4), Theatre (T1-3), a University (U) and a Research Institute (RI). TBOEP is not indicated as it was a semi quantitative estimation. 
equipped with a 7000 A GC-MS Triple Quadrupole, and electron ionization (EI) was set at $70 \mathrm{eV}$. The column used was a DB-5MS with $15 \mathrm{~m}$ (length) $\times 0.250 \mathrm{~mm}$ (I. D.) $\times 0.10 \mu \mathrm{m}$ (film) $(\mathrm{J \& W}$ Scientific, USA). GC-MS/MS conditions were used as described elsewhere (Cristale and Lacorte, 2013; Cristale et al., 2012).

\subsection{Principal Component Analysis (PCA)}

Principal Component Analysis (PCA) (Farnham et al., 2002) was used to determine the contamination patterns in dust samples (Wold et al., 1987). A data matrix of 14 rows (equal to the number of samples) and 16 columns (corresponding to the 16 compounds with detection frequency $>50 \%$ ) was arranged. Values below detection limit were replaced by $1 / 2$ LOD. Autoscaling was used to give similar weight to the different variables (analyzed FR) and eliminate offsets. PCA calculations were performed using the PLS Toolbox v7.8 (Eigenvector Research Inc., Wenatche, WA, USA) working under MATLAB 2013b (The Mathworks, Natick, MA, USA).

\section{Results}

\subsection{Flame retardant occurrence in dust samples}

In this study, 8 PBDEs, 9 NBFRs and 10 OPFRs were determined in dust samples collected in homes and public places (theatres, schools, university and research institute) from Barcelona in order to evaluate their occurrence/levels and estimate their distribution. All types of FRs were simultaneously detected and Fig. 1 presents the concentrations of OPFRs, PBDEs and NBFRs in dust samples. OPFRs was the most abundant family of FRs, followed by PBDEs. $\sum_{9}$ OPFRs ranged from 2053 to $72,090 \mathrm{ng} \mathrm{g}^{-1}$ and the most abundant compound was TCIPP. TBOEP was also detected in all dust samples at a semi quantitative estimated concentration between 1000 and $80,000 \mathrm{ng} \mathrm{g}^{-1}$. BDE-209 was the most abundant PBDE congener (up to $14,990 \mathrm{ng} \mathrm{g}^{-1}$ ), while the sum of the other PBDEs ( $\sum_{7}$ PBDEs) ranged from 3.0 to $184 \mathrm{ng} \mathrm{g}^{-1}$. Among the studied NBFRs, DBDPE ( up to $4432 \mathrm{ng} \mathrm{g}^{-1}$ ) followed by BEH-TEBP ( up to $508 \mathrm{ng} \mathrm{g}^{-1}$ ) were the most abundant ones whereas a lower detection frequency was observed for EH-TBB, BTBPE, PBT and HBB. Some flame retardants were not detected, namely BDE-28, PBEB, DBHCTD and TBP-DBPE.

The highest content of flame retardants in dust was observed for the theatre samples, which was attributed to the use of large amounts of materials containing flame retardants (e.g., polyurethane foam, textiles, carpets, electronic equipment) that results in high emissions of FR and their accumulation in dust particles. Homes presented the second highest concentrations followed by
U/RI, while schools presented the lowest FR levels.

Since FR usage is dependent of the type of material, FR profiles in indoor dust may vary depending on the characteristics of each indoor site (e.g. EEE, furniture, construction materials, etc.). Examining at individual results, FR vary in both levels and profiles according to the specific environment. For example, among theatres, T2 presented the lowest levels of FRs and this is attributed to the fact that this theatre was rebuilt and was not yet in use at the time of sampling, indicating that although FR were present, they were not as widely distributed or emitted from in-use products to the surrounding air and dust. The highest contribution was for chloroalkyl and aryl phosphates and BDE-209.

Considering the house sample group, BDE-209 was detected in all houses but was at the highest concentrations in $\mathrm{H} 5$, which is an old house with very old furniture. $\mathrm{H} 4$ presented much higher levels of NBFRs than other house dust samples, which might be attributed to the large amounts of EEE, as one of the dwellers is an electronic engineer and as hobby deals with the assembly and production of electronic motors and other apparatuses. Printed circuit boards, plastics and internal and external wiring contain flame retardants as a measure to avoid flammability at the high temperatures that these systems operate. Specifically, H4 contained high amounts of HBB and DBDPE. HBB is used in polymers, plastics, and electric manufactured goods and electronic devices (Covaci et al., 2011) and may enter the house environment as a fugitive emission from its use. DBDPE was introduced to the market in 1992 as an alternative to BDE-209 and used in applications similar to those in which the deca-BDE technical mixture was used. DBDPE is known to have been used in EEE (Betts, 2009; Schlummer et al., 2007) but also as adhesive and sealants and plastics (polyester vinyl ester resins, rubbers). The presence of higher concentrations of DBDPE compared to BDE-209 in H4 indicates that electronic equipment may be an evident source of this compound as DBDPE has been marketed as general purpose substitute for Deca-BDE. A very similar profile was observed for $U$ and RI, although the concentrations detected were lower.

Schools had a low contribution of most FRs, being OPFRs the compounds present at the highest concentration. Remarkably, schools did not present any significant contribution of NBFRs, except for BEH-TEBP, while BDE-209 was present at detectable levels only for S1 and S2. However, S3 had a high contribution of TBOEP (estimated levels of $60,000 \mathrm{ng} \mathrm{g}^{-1}$ ).

The presence of FRs in dust is related to current regulations. For example, regulations that prohibit the use of PBDEs (ECJ, 2008; OJEU, 2003a, 2003b, 2005) involve the use of alternative substances in industrial formulations or final objects in order to reach fire safety standards, and so the profile of FRs in dust tend to change as new products are acquired and old ones are being
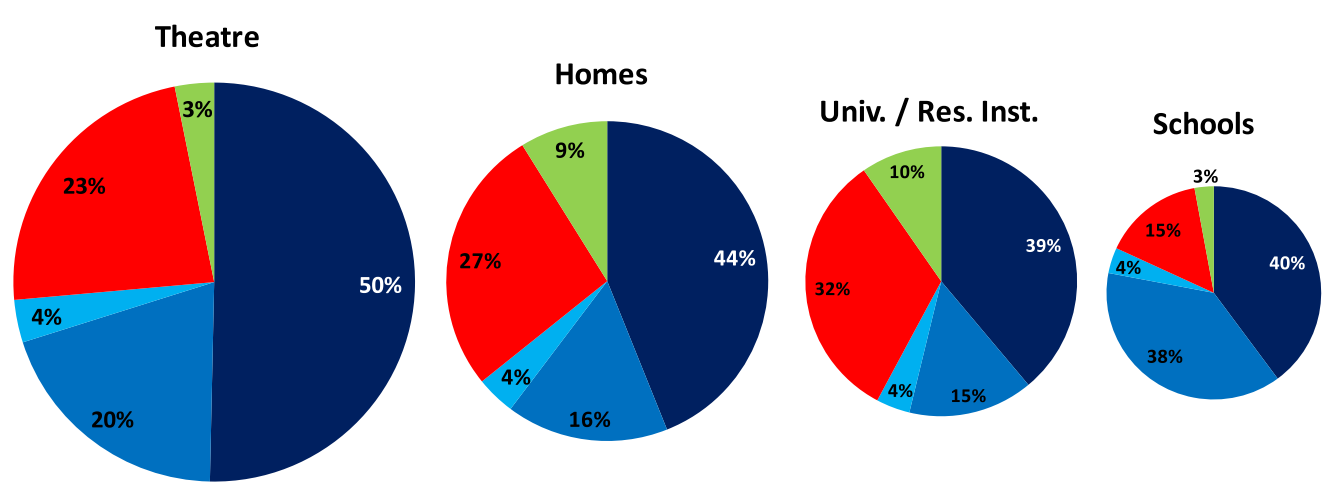

¿ChlAlkP

$\square$ IAryP

- $\sum$ AlkP

- $\sum$ PBDE

INBFRs 
substituted. A comparison among the content of FRs in dust samples permitted to identify the patterns concerning FR presence in indoor dust from different environments. Fig. 2 presents the average profile of the different families of flame retardants in each studied environment. OPFRs were divided in three groups: chloroalkyl phosphates ( $\Sigma$ ClhAlkP - TCEP, TCIPP, TDCIPP), alkyl phosphates ( $\sum$ AlkP - TIBP, TNBP, TEHP) and aryl phosphates ( $\sum$ AryP TPHP, EHDPHP, TMPP). Concerning OPFRs, the chloroalkyl phosphates were the most abundant ones in most of the studied indoor sites. The main application of TCEP, TCIPP and TDCIPP is in rigid and flexible polyurethane foam (EURAR, 2008a, 2008b; SCHER, 2012). Among all the studied places, theatres had the highest percentage content of chloroalkyl phosphates, which is in accordance with the presence of huge amounts of those materials (e. g., roofing insulation and upholstery). Alkyl and aryl phosphates are plasticizers with flame retardant properties applied to different materials such as PVC, synthetic rubbers, cellulose based plastics, synthetic resins and hydraulic fluids, among other (WHO, 2000; van der Veen and de Boer, 2012). Interestingly, the average percentage content of alkyl phosphates (4\%) was similar in all environments. It is possible that they originate from similar sources, but such hypothesis cannot be tested with a limited amount of samples. On the other hand, aryl phosphates were predominant in schools.

For PBDEs, the influence of penta- and octa-BDEs was low in all analyzed samples, while BDE-209 was responsible for $94-100 \%$ of total PBDE content. The main application of BDE-209 is in high impact polystyrene (HIPS) (WSU, 2006), often used in electronic enclosures. After the ban of deca-BDE in electric and electronic equipment in Europe after 2008 (ECJ, 2008), NBFRs have been introduced in the market (Covaci et al., 2011), specifically DBDPE used as BDE-209 substitute. Other NBFR used in electronic enclosures is BTBPE, which is applied in HIPS, ABS and other polymers (Covaci et al., 2011).

An insight at the flame retardant profiles in each studied environment (Fig. 2) shows a higher contribution of brominated flame retardants in homes, university/research institute and theatres than in schools. This behaviour can be related to the presence of higher amounts of electric and electronic equipments in these places than in schools. In addition, homes and university/ research institute had a higher content of NBFRs than the other places. This fact could be related to the higher replacement frequency of EEEs in these environments, as new acquired equipments should contain PBDE substitutes, such as NBFRs, following european regulations.

\subsection{Distribution of FRs using PCA}

PCA was used to determine the distribution of the different FR in dust samples and to evaluate multivariate correlations among samples. In the PCA data matrix, built up with 14 dust samples and the 16 most frequent compounds detected, $47.51 \%$ of the variance was explained using 2 Principal Components (PCs). Considering all dust samples, PCA revealed differences in FR patterns. Fig. 3a indicates the score plot of the different types of samples studied. The first PC (PC1) explained $31.67 \%$ of the total data variance and the second PC (PC2) explained the 15.84\%. The cluster of school samples (S, blue triangles) correspond to a low contribution of all FRs. $\mathrm{U}$ and RI also show low levels of OPFRs although some contribution of NBFRs. Homes $(\mathrm{H})$ distributed along with PC1 axis and
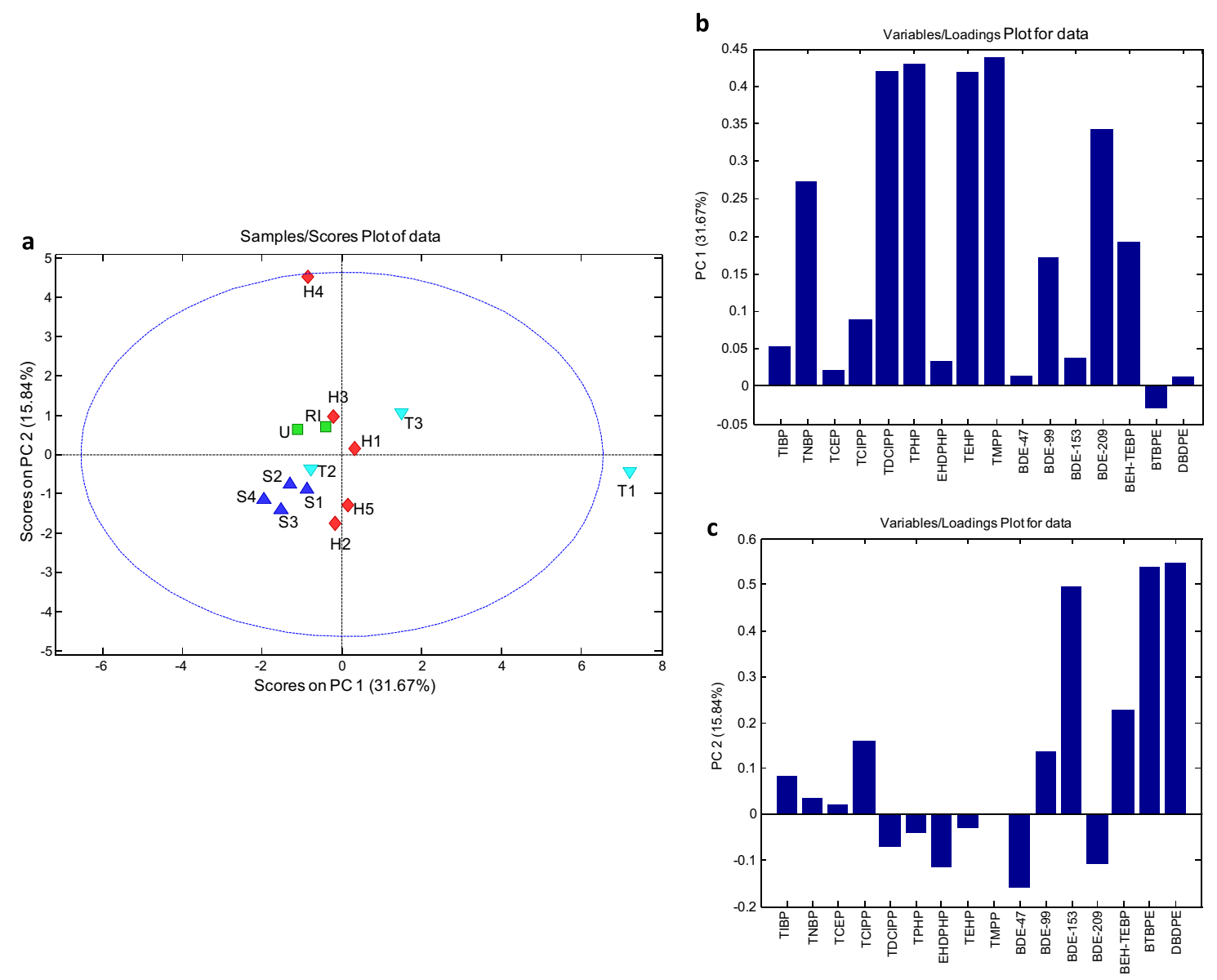

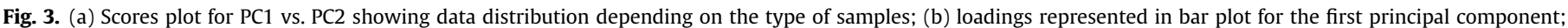
(c) loadings for the second principal component. 
Table 2

PBDEs concentration (ng g ${ }^{-1}$ ) in dust samples from different countries.

\begin{tabular}{|c|c|c|c|c|c|c|c|c|c|c|}
\hline COUNTRY & Sampling method (size fraction) & Sampling site & BDE-28 & BDE-47 & BDE-99 & BDE-100 & BDE-153 & BDE-154 & BDE-183 & BDE-209 \\
\hline \multirow[t]{4}{*}{ This study $^{\mathrm{a}}$} & \multirow[t]{4}{*}{$\operatorname{VCDB}(<500 \mu \mathrm{m})$} & Homes $(n=5)$ & nd & $7.3^{*}$ & $5.9^{*}$ & $\mathrm{nd}^{*}$ & 7.9* & $\mathrm{nd}^{*}$ & $33.4^{*}$ & $3526^{*}$ \\
\hline & & Schools $(\mathrm{n}=4)$ & nd & nd* & nd & nd & nd & nd & nd & $710^{*}$ \\
\hline & & Theatres $(\mathrm{n}=3)$ & nd & $9.2^{*}$ & $16.4^{*}$ & $10.9^{*}$ & $5.7^{*}$ & $\mathrm{nd}^{*}$ & nd & $4754^{*}$ \\
\hline & & Res. Institution $(\mathrm{n}=2)$ & nd & $13.9^{*}$ & 22.7 & $6.2^{*}$ & $10.3^{*}$ & $9.3^{*}$ & $60.1^{*}$ & $2509^{*}$ \\
\hline \multirow[t]{2}{*}{ Oslo, Norway (Cequier et al., 2014) } & \multirow[t]{2}{*}{$\operatorname{VCDCR}(<1-3 \mathrm{~mm})$} & Residential living rooms ( $\mathrm{n}=47$ ) & $0.688^{*}$ & $126^{*}$ & $171^{*}$ & $33.1^{*}$ & $26.0^{*}$ & $12.7^{*}$ & $3.22^{*}$ & 325 * \\
\hline & & School classrooms $(n=6)$ & $0.371^{*}$ & $46.9^{*}$ & $42.4^{*}$ & $7.95^{*}$ & 8.93* & $5.76^{*}$ & $5.80^{*}$ & 507 * \\
\hline Munich, Germany (Fromme et al., 2014) & $\operatorname{VCBD}(<63 \mu \mathrm{m})$ & Homes $(n=20)$ & $0.1^{*}$ & $5.7^{*}$ & $9.2^{*}$ & $1.6^{*}$ & $2.1^{*}$ & $1.1^{*}$ & $9.3^{*}$ & $950^{*}$ \\
\hline \multirow[t]{2}{*}{ California, US (Bennett et al., 2015) } & \multirow[t]{2}{*}{$\operatorname{VCBD}(<150 \mu \mathrm{m})$} & Homes with young children & - & $1300^{*}$ & $1400^{*}$ & $280^{*}$ & $150^{*}$ & $160^{*}$ & - & $2400^{*}$ \\
\hline & & Homes with older adults & & $840^{*}$ & $960^{*}$ & $190^{*}$ & $120^{*}$ & $79^{*}$ & & $1100^{*}$ \\
\hline \multirow[t]{2}{*}{ Japan (Mizouchi et al., 2015) } & \multirow[t]{2}{*}{$\operatorname{VCDCR}(<250 \mu \mathrm{m})$} & Homes $(\mathrm{n}=10)$ & $0.638^{* *}$ & $5.647^{* *}$ & $6.109^{* *}$ & $1.304^{* *}$ & $15.231^{* *}$ & $1.678^{* *}$ & $71.42^{* *}$ & $1429^{* * *}$ \\
\hline & & Elementary school $(n=18)$ & $2.539^{* *}$ & $8.919^{* *}$ & $7.894^{* *}$ & $1.630^{* *}$ & $2.820^{* * *}$ & $1.265^{* *}$ & $13.24^{* *}$ & $995.4^{* *}$ \\
\hline \multirow[t]{4}{*}{ China (Zhu et al., 2015) } & \multirow[t]{4}{*}{ Brush sampling } & Urban homes $(\mathrm{n}=28)$ & - & - & - & - & - & - & - & $800^{* * * *}$ \\
\hline & & Rural homes $(\mathrm{n}=15)$ & & & & & & & & 550 *** \\
\hline & & Urban public place $(n=27)$ & & & & & & & & $1850^{* * *}$ \\
\hline & & Rural public place $(n=8)$ & & & & & & & & $300^{* * *}$ \\
\hline \multirow[t]{4}{*}{ Seoul and satellite cities, Korea (Lim et al., 2014) } & \multirow{4}{*}{$\operatorname{VCBD}(<500 \mu \mathrm{m})$} & Homes (floor dust) $(\mathrm{n}=30)$ & $0.8^{* *}$ & $3.2^{* *}$ & $14.2^{* *}$ & $0.8^{* *}$ & $218.9 * *$ & $25.6^{* *}$ & $25.6^{* *}$ & $4353.8^{* * *}-1-x-1$ \\
\hline & & Elementary schools $(n=30)$ & $2.8^{* *}$ & $222.2^{* *}$ & $215.8^{* *}$ & $67.7^{* *}$ & $29.8^{* *}$ & $18.0^{* *}$ & $18.0^{* *}$ & $4195.2^{* *}$ \\
\hline & & Private academies $(n=31)$ & $7.6^{* *}$ & $46.2^{* *}$ & $42.2^{* *}$ & $6.9^{* *}$ & $32.6^{* *}$ & $10.1^{* *}$ & $237.3^{* *}$ & $6267.0^{* *}$ \\
\hline & & Public facilities $(n=8)$ & $2.2^{* *}$ & $151.0^{* *}$ & $147.9^{* *}$ & $45.8^{* *}$ & $79.9^{* *}$ & $18.7^{* *}$ & $95.7^{* *}$ & $4454.8^{* *}$ \\
\hline \multirow[t]{2}{*}{ Cairo, Egypt (Hassan and Shoeib, 2015) } & \multirow[t]{2}{*}{$\operatorname{VCBD}(<250 \mu \mathrm{m})$} & Homes $(\mathrm{n}=17)$ & $0.34^{*}$ & $1.7^{*}$ & $2.7^{*}$ & $0.37^{*}$ & $6.26^{*}$ & $0.38^{*}$ & $1.1^{*}$ & $40.2^{*}$ \\
\hline & & Workplace $(\mathrm{n}=9)$ & $0.39^{*}$ & $2.3^{*}$ & $7.1^{*}$ & $0.6^{*}$ & $32.9^{*}$ & $0.83^{*}$ & $2.3^{*}$ & $366^{*}$ \\
\hline
\end{tabular}

nd - not detected (in any sample).

$\mathrm{nd}^{*}$ - not detected is the median value.

(-) not studied.

${ }^{* *}$ Median.

Average.

${ }^{\text {a }}$ Non detected values were represented numerically as half detection limit for median calculation. 
Table 3

NBFRs concentration $\left(\mathrm{ng} \mathrm{g}^{-1}\right)$ in dust samples from different countries.

\begin{tabular}{|c|c|c|c|c|c|c|c|c|}
\hline COUNTRY & $\begin{array}{l}\text { Sampling method (particle size } \\
\text { fraction) }\end{array}$ & Sampling site & PBT & HBB & EH-TBB & ВТВРЕ & $\begin{array}{l}\text { BEH- } \\
\text { TEBP }\end{array}$ & DBDPE \\
\hline \multirow[t]{4}{*}{ This study ${ }^{a}$} & \multirow[t]{4}{*}{$\operatorname{VCDB}(<500 \mu \mathrm{m})$} & Homes $(n=5)$ & $\mathrm{nd}^{*}$ & $\mathrm{nd}^{*}$ & $\mathrm{nd}^{*}$ & $21.4^{*}$ & $21.4^{*}$ & $307^{*}$ \\
\hline & & Schools $(n=4)$ & nd & nd & nd & nd & $150^{*}$ & nd* \\
\hline & & Theatres $(n=3)$ & nd & nd & $\mathrm{nd}^{*}$ & $19.9^{*}$ & $344^{*}$ & $647^{*}$ \\
\hline & & Res. Institution $(\mathrm{n}=2)$ & nd & nd & $8.1^{*}$ & $24.6^{*}$ & $189^{*}$ & 596 \\
\hline \multirow[t]{2}{*}{ Oslo, Norway (Cequier et al., 2014) } & \multirow[t]{2}{*}{$\operatorname{VCDCR}(<1-3 \mathrm{~mm})$} & $\begin{array}{l}\text { Residential living rooms } \\
(\mathrm{n}=47)\end{array}$ & $0.633^{*}$ & $0.671^{*}$ & 2.54 & $3.76^{*}$ & $78.5^{*}$ & $147^{*}$ \\
\hline & & School classrooms $(n=6)$ & $0.232^{*}$ & $0.901^{*}$ & $3.32^{*}$ & $6.55^{*}$ & $103^{*}$ & $156^{*}$ \\
\hline Munich, Germany (Fromme et al., 2014) & $\operatorname{VCBD}(<63 \mu \mathrm{m})$ & Homes $(n=20)$ & - & - & $4.2^{* * *}$ & $10^{* *}$ & $436^{* *}$ & $323^{* *}$ \\
\hline $\begin{array}{l}\text { Washington State, US (Schreder and La } \\
\text { Guardia, 2014) }\end{array}$ & $\operatorname{VCDCR}(<300 \mu \mathrm{m})$ & Homes $(n=20)$ & - & - & 190 & $70^{*}$ & $115^{*}$ & $173^{*}$ \\
\hline Boston, US (Stapleton et al., 2009) & $\operatorname{VCBD}(<150 \mu \mathrm{m})$ & Homes $(n=50)$ & - & - & $840^{* * * *}$ & $21^{* * * *}$ & $650^{* * * *}$ & - \\
\hline \multirow[t]{2}{*}{ Japan (Mizouchi et al., 2015) } & \multirow[t]{2}{*}{ VCDCR $(<250 \mu \mathrm{m})$} & Homes $(n=10)$ & - & - & - & - & - & 220 \\
\hline & & Elementary school $(\mathrm{n}=18)$ & & & & & & 50 \\
\hline \multirow[t]{2}{*}{ New Zealand (Ali et al., 2012) } & \multirow[t]{2}{*}{ VCDCR } & $\begin{array}{l}\text { Homes - living room floor } \\
(\mathrm{n}=34)\end{array}$ & - & - & 2 & $2^{*}$ & $12^{*}$ & $23^{*}$ \\
\hline & & Homes - mattresses $(n=16)$ & & & 3 & $1^{*}$ & $1^{*}$ & $9 *$ \\
\hline \multirow[t]{2}{*}{ Cairo, Egypt (Hassan and Shoeib, 2015) } & \multirow[t]{2}{*}{$\operatorname{VCBD}(<250 \mu \mathrm{m})$} & Homes $(n=17)$ & - & $0.1^{*}$ & $0.8^{*}$ & $0.2^{*}$ & $0.1^{*}$ & - \\
\hline & & Workplace $(n=9)$ & & $0.05^{*}$ & $7.1^{*}$ & $1.3^{*}$ & $0.09 *$ & \\
\hline
\end{tabular}

nd - not detected (in any sample).

$\mathrm{nd}^{*}$ - not detected is the median value.

(-) not studied.

* Median

${ }^{* *}$ Average.

*** Geometric mean.

${ }^{\text {a }}$ Non detected values were represented numerically as half detection limit for median calculation

theatres (T) distributed along the PC2 axis suggest that they are influenced by two completely different factors.

The loadings plot for the first PC (Fig. 3b) was clearly explained by the presence of OPFRs, namely TDCIPP, TPHP, TEHP and TMPP, and BDE-209. The high loadings of these compounds indicate their co-occurrence and that these flame retardants/plasticizers are present in all environments as a general contamination pattern. The loadings of PC2 (Fig. 3c), describe an average diffusion contamination pattern associated to the general use of NBFRs (BEHTEBP, BTBPE, and DBDPE) and BDE-153. The presence of these compounds was exemplified basically in $\mathrm{H} 4$ and in a minor extent, $\mathrm{H} 1, \mathrm{H} 3, \mathrm{U}, \mathrm{RI}$ and T3. In this PC, the positive loading of DBDPE contrasts with the negative loadings of BDE-209 and indicates different sources in dust samples.

Theatres $(\mathrm{T})$ had a dissimilar pattern, where $\mathrm{T} 1$ and $\mathrm{T} 3 \mathrm{had}$ a high contribution of OPFRs, contrary to T2 (the new theatre) which had a low contribution of all FRs. T1 was out of the confidence level due to the high levels of OPFRs and BDE-209 (high contribution in PC1). H were distributed along the zero axis of PC1, indicating a general contribution of OPFRs and whereas $\mathrm{H} 3$ and $\mathrm{H} 4$ have a high contribution of NBFRs as they are positive of PC2 axis, $\mathrm{H} 2$ and $\mathrm{H} 5$, the oldest houses, have high contributions of BDE-209 and BDE-47 and are negative of the PC2 axis. Therefore, PCA permitted to cluster dust samples according to types of indoor environments.

\subsection{Comparison to other studies}

Comparison of FR levels among studies is complicated and has to be performed carefully since differences in sampling and sample treatment methodologies affect the measured concentration. The most popular dust sampling methodology involve the use of common vacuum cleaners, and samples can be obtained directly by simple collection of vacuum cleaner bags (Fromme et al., 2014; Lim et al., 2014; Stapleton et al., 2009) or by vacuuming floor and surfaces (Cequier et al., 2014; Mizouchi et al., 2015; Schreder and La Guardia, 2014). The use of vacuum cleaner bag dust (VCBD) samples is an interesting way to obtain a large number of samples from different places and have been used in source characterization and exposure assessment studies (Colt et al., 1998; Lim et al., 2014; Stapleton et al., 2009). Alternatively, vacuum cleaner dust collected by researchers (VCDCR) allows sampling from specific areas (e.g. floors, surfaces, upholstery, etc.) or rooms, and have been used in human exposure and epidemiological studies (Araki et al., 2014; Cequier et al., 2014; He et al., 2015; Mizouchi et al., 2015). However, the best dust sampling method (VCBD or VCDCR) for human exposure assessment is still undetermined (Björklund et al., 2012). Allen et al. compared the levels of VCBD and VCDCR methodologies and observed that concentration using VCBD were significantly lower (and not strongly correlated) than the concentration collected using VCDCR in rooms with potential PBDEs sources at the same house (Allen et al., 2008). These authors also observed that PBDE concentration in different rooms were also significantly different, indicating that sources in each microenvironment influence PBDE distribution in house dust. In another study, concentrations of PBDEs in VCBD were lower than the concentration in VCDCR from surfaces at least $1 \mathrm{~m}$ above the floor (Björklund et al., 2012). Finally, the particle size fraction used for FR measurement in dust also has an influence on FR concentration. Cao et al. (2014) observed that concentrations of PBDEs, NBFRs and OPFRs in dust do not constantly increase with the decrease in the particle size, and that peak concentration generally occur at particle size around 900, 100 and $10 \mu \mathrm{m}$.

Therefore, given that FR concentration is dependent on the fraction size and the sampling methodology, FR levels among studies that used different sampling strategies and different sieving grade cannot be directly compared. Table 2-4 presents the concentration, sampling methodology and fraction size used for the determination of PBDEs, NBFRs and OPFRs in indoor dust collected in different countries. Few studies that used VCBD and fraction size $<500 \mu \mathrm{m}$ were reported for comparison to this study. Concentrations of PBDEs from homes and schools from Korea (Lim et al., 2014) were somewhat higher than the observed in this study (Fig. 1), with average levels ranging from $2.8 \mathrm{ng} \mathrm{g}^{-1}$ (BDE-28) to 
Table 4

OPFRs concentration ( $\mathrm{ng} \mathrm{g}^{-1}$ ) in dust samples from different countries.

\begin{tabular}{|c|c|c|c|c|c|c|c|c|c|c|c|c|}
\hline COUNTRY & $\begin{array}{l}\text { Sampling method } \\
\text { (particle size } \\
\text { fraction) }\end{array}$ & Sampling site & TIBP & TNBP & TCEP & TCIPP & TDCIPP & TPHP & EHDPHP & ТВОЕР & TEHP & TMPP \\
\hline \multirow[t]{4}{*}{ This study ${ }^{\mathrm{a}}$} & \multirow[t]{4}{*}{$\operatorname{VCDB}(<500 \mu \mathrm{m})$} & Homes $(n=5)$ & $143^{*}$ & $121^{*}$ & $1790^{*}$ & $2623^{*}$ & $706^{*}$ & $1102^{*}$ & $1262^{*}$ & detected & $454^{*}$ & $278^{*}$ \\
\hline & & Schools $(n=4)$ & $38.6^{*}$ & $44.6^{*}$ & $139^{*}$ & $2149^{*}$ & 172 & $604^{*}$ & $772^{*}$ & detected & $71.9^{*}$ & $28.5^{*}$ \\
\hline & & Theatres $(n=3)$ & $47.5^{*}$ & $116^{*}$ & $718^{*}$ & 4328 & $725^{*}$ & $4010^{*}$ & 1032 & detected & 266 & $868^{*}$ \\
\hline & & Res. Institution $(\mathrm{n}=2)$ & $220^{*}$ & 31.4 & $244^{*}$ & $2211^{*}$ & $738^{*}$ & $460^{*}$ & $630^{*}$ & detected & $92.4^{*}$ & 172 \\
\hline \multirow[t]{2}{*}{$\begin{array}{l}\text { Oslo, Norway (Cequier } \\
\text { et al., 2014) }\end{array}$} & \multirow[t]{2}{*}{$\operatorname{VCDCR}(<1-3 \mathrm{~mm})$} & $\begin{array}{l}\text { Residential living rooms } \\
(\mathrm{n}=47)\end{array}$ & - & $55.0^{*}$ & $414^{*}$ & $2680^{*}$ & $501^{*}$ & $981^{*}$ & $617^{*}$ & $13,400^{*}$ & - & $307^{*}$ \\
\hline & & School classrooms $(n=6)$ & & $43.5^{*}$ & $1210^{*}$ & $2040^{*}$ & $1490^{*}$ & $1540^{*}$ & $2340^{*}$ & $87,200 *$ & & $56.4^{*}$ \\
\hline \multirow{2}{*}{$\begin{array}{l}\text { Felimish, Belgium (Van den } \\
\text { Eede et al., 2011) }\end{array}$} & \multirow{2}{*}{$\operatorname{VCDCR}(<500 \mu \mathrm{m})$} & Homes $(\mathrm{n}=33)$ & $2990^{*}$ & $130^{*}$ & $230^{*}$ & $1380^{\prime \prime}$ & $360^{*}$ & $500^{*}$ & - & $2030^{*}$ & - & $240^{*}$ \\
\hline & & Store dust $(n=15)$ & $1040^{*}$ & $210^{*}$ & $590^{*}$ & $2940^{*}$ & $760^{*}$ & 1970 & & $3610^{*}$ & & $200^{*}$ \\
\hline $\begin{array}{l}\text { Boston, US (Stapleton et al., } \\
\text { 2009) }\end{array}$ & $\operatorname{VCBD}(<150 \mu \mathrm{m})$ & Homes $(n=50)$ & - & - & - & $572^{* * * *}$ & $1890^{* * *}$ & $7360^{* * *}$ & - & - & - & - \\
\hline $\begin{array}{l}\text { Washington State, US } \\
\text { (Schreder and La Guar- } \\
\text { dia, 2014) }\end{array}$ & $\operatorname{VCDCR}(<300 \mu \mathrm{m})$ & Homes $(n=20)$ & - & - & $1380^{*}$ & $4820^{*}$ & $1620^{*}$ & - & - & - & - & - \\
\hline \multirow{2}{*}{ Japan (Mizouchi et al., } & \multirow[t]{2}{*}{$\operatorname{VCDCR}(<250 \mu \mathrm{m})$} & Homes $(n=10)$ & nd & $130^{*}$ & $2700^{*}$ & $1700^{\prime \prime}$ & $2200^{*}$ & $820^{*}$ & $200^{*}$ & $82,000^{*}$ & nd* $^{*}$ & $1200^{*}$ \\
\hline & & Elementary school $(n=18)$ & nd* & $\mathrm{Nd}^{*}$ & $500^{*}$ & $630^{*}$ & $740^{*}$ & $2200^{*}$ & $400^{*}$ & 270,000 & nd* & $6800^{*}$ \\
\hline \multirow{2}{*}{$\begin{array}{l}\text { Sapporo, Japan (Tajima } \\
\text { et al., 2014) }\end{array}$} & \multirow[t]{2}{*}{$\operatorname{VCDCR}(<250 \mu \mathrm{m})$} & Homes floor $(n=48)$ & - & $\mathrm{nd}^{*}$ & $\mathrm{nd}^{*}$ & $740^{*}$ & $\mathrm{nd}^{*}$ & $870^{*}$ & - & $30,880^{*}$ & nd* & nd \\
\hline & & $\begin{array}{l}\text { Homes upper surfaces } \\
(n=128)\end{array}$ & & $740^{*}$ & $1170^{*}$ & 2230 & nd* & 3130 & & $26,550^{*}$ & $\mathrm{nd}^{*}$ & nd \\
\hline \multirow[t]{4}{*}{$\begin{array}{l}\text { Southern China (He et al., } \\
\text { 2015) }\end{array}$} & \multirow[t]{4}{*}{$\operatorname{VCDCR}(<100 \mu \mathrm{m})$} & $\begin{array}{l}\text { Rural e-waste workshop } \\
(n=17)\end{array}$ & - & $280^{*}$ & $930^{*}$ & $4770^{*}$ & $410^{*}$ & $4270^{*}$ & $580^{*}$ & 240 & $250^{*}$ & $9510^{*}$ \\
\hline & & Rural home $(n=25)$ & & $140^{*}$ & $1930^{\circ}$ & $1220^{*}$ & 150 & $1090^{*}$ & $310^{*}$ & $200^{*}$ & $190^{*}$ & nd* \\
\hline & & Urban home $(\mathrm{n}=11)$ & & $80^{*}$ & $3780^{*}$ & $750^{*}$ & $130^{*}$ & $150^{*}$ & $360^{*}$ & $320^{*}$ & $140^{*}$ & nd $^{*}$ \\
\hline & & $\begin{array}{l}\text { Urban college dormitory } \\
(n=15)\end{array}$ & & $100^{*}$ & $7940^{*}$ & $480^{*}$ & $130^{*}$ & 120 & $270^{*}$ & $280^{*}$ & $160^{*}$ & $\mathrm{nd}^{*}$ \\
\hline \multirow{2}{*}{$\begin{array}{l}\text { Philippines (Kim et al., } \\
\text { 2013) }\end{array}$} & \multirow[t]{2}{*}{$\operatorname{VCBD}(<500 \mu \mathrm{m})$} & Homes (Maleate) $(\mathrm{n}=17)$ & - & $19^{*}$ & $34^{*}$ & - & - & $89^{*}$ & $110^{*}$ & - & $140^{*}$ & $18^{*}$ \\
\hline & & Homes (Payatas) $(\mathrm{n}=20)$ & & $20^{*}$ & $16^{*}$ & & & $71^{*}$ & $34^{*}$ & & $41^{*}$ & $7.7^{*}$ \\
\hline \multirow[t]{2}{*}{$\begin{array}{l}\text { New Zealand (Ali et al., } \\
\text { 2012) }\end{array}$} & \multirow[t]{2}{*}{ VCDCR } & $\begin{array}{l}\text { Homes - living room floor } \\
(\mathrm{n}=34)\end{array}$ & - & $80^{*}$ & $110^{*}$ & $350^{*}$ & $230^{*}$ & $600^{*}$ & - & $4020^{*}$ & - & $120^{*}$ \\
\hline & & $\begin{array}{l}\text { Homes - mattresses } \\
(\mathrm{n}=16)\end{array}$ & & $70^{*}$ & $40^{*}$ & $250^{*}$ & $110^{*}$ & $240^{*}$ & & $1550^{*}$ & & $160^{*}$ \\
\hline \multirow{4}{*}{$\begin{array}{l}\text { Assiut, Egypt (Abdallah and } \\
\text { Covaci, 2014) }\end{array}$} & \multirow[t]{4}{*}{$\operatorname{VCDCR}(<500 \mu \mathrm{m})$} & Homes $(n=20)$ & $23^{*}$ & $17^{*}$ & $22^{*}$ & $28^{*}$ & $72^{*}$ & $67^{*}$ & $42^{*}$ & $18^{*}$ & - & - \\
\hline & & Offices $(n=20)$ & $28^{*}$ & $23^{*}$ & $31^{*}$ & $80^{*}$ & $49^{*}$ & $73^{*}$ & $48^{*}$ & $143^{*}$ & & \\
\hline & & Cars $(n=20)$ & $51^{*}$ & $59^{*}$ & $127^{*}$ & $291^{*}$ & $61^{*}$ & $135^{*}$ & 54 & $190^{*}$ & & \\
\hline & & $\begin{array}{l}\text { Public microenvironments } \\
(\mathrm{n}=11)\end{array}$ & $133^{*}$ & $73^{*}$ & 234 & 232 & $416^{*}$ & $629^{*}$ & $44^{*}$ & $68^{*}$ & & \\
\hline
\end{tabular}

nd - not detected (in any sample).

nd $^{*}$ - not detected is the median value.

$(-)$ not studied.

${ }^{\text {a }}$ Non detected values were represented numerically as half detection limit for median calculation.

* Median.

${ }^{* * *}$ Geometric mean.

$4195 \mathrm{ng} \mathrm{g}^{-1}$ (BDE-209), while in this study only BDE-209 was detected in schools (up to $3071 \mathrm{ng} \mathrm{g}^{-1}$ ). On the other hand, median concentrations of OPFRs in this study (ranging from $121 \mathrm{ng} \mathrm{g}^{-1}$ (TNBP) to $2623 \mathrm{ng} \mathrm{g}^{-1}$ (TCIPP)) were much higher than the reported for homes from Philippines (ranging from $7.7 \mathrm{ng} \mathrm{g}^{-1}$ (TEHP) to $140 \mathrm{ng} \mathrm{g}^{-1}$ (TMPP)) (Kim et al., 2013). Differences in FR levels in indoor dust between places can be attributed to different types, features and qualities of construction materials with concomitant varying amounts of flame retardants, which are reflected in different profiles in each indoor environment.

Concerning FR profile in dust, few studies reporting simultaneous presence of PBDEs, NBFRs and OPFRs are available for a comparison with the results herein obtained. Mizouchi et al. reported the concentration of OPFRs, PBDEs, DBDPE and hexabromocyclododecane (HBCD) in dust from Japanese elementary schools and homes (Mizouchi et al., 2015). Similarly to this study, OPFRs were present at higher concentrations than PBDEs, and high contribution of chloroalkyl phosphates were detected in homes. Specifically, Japanese schools presented much higher concentrations of TBOEP than houses, attributed to the intense use of floor polisher/wax in schools, a trend that was also observed in this study for S3 (a kindergarten). OPFRs were also more abundant than PBDEs and NBFRs in homes and schools from Norway (Cequier et al., 2014) and United States homes (Schreder and La Guardia, 2014). Concerning brominated flame retardants, this study presented the same profile than those reported in several other studies where BDE-209 was the most abundant PBDE and DBDPE the most abundant NBFR (Cequier et al., 2014; Fromme et al., 2014; Hassan and Shoeib, 2015; Lim et al., 2014; Mizouchi et al., 2015; Zhu et al., 2015). On the other hand, Washington State homes presented higher levels of penta-BDEs, and BEH-TEBP, EHTBB and DBDPE were present at similar levels (Schreder and La Guardia, 2014). Differences among profiles of FRs in dust are influenced by FR formulations that are mostly used for materials manufactory in each country/commercial region. US have an historical intensive use of penta-BDE formulation in polyurethane foam (Hale et al., 2002), which support the higher levels of BDE-47, 99 and 100 in dust from US than from Europe. Additionally, differences on the BEH-TEBP/EH-TBB proportion found for US and European dust samples indicate the use of different FR formulations containing these NBFRs (Cequier et al., 2014; Newton et al., 2015). The formulation Firemaster ${ }^{\circledR} 550$ (Chemtura) have an approximate EH-TBB/BEH-TEBP ratio of $4: 1$ (by mass) (Stapleton et al., 2008) and is used in polyurethane foam. Given that no 
correlation was observed between EH-TBB and BEH-TEBP, the later present at much higher concentrations, these results indicate that this formulation is not extensively used in the study area. Other FR formulations which contain mixtures of these FRs are BZ-54 (70\% of EH-TBB and 30\% of BEH-TEBP) and BZ-45 (only BEH-TEBP) (Zheng et al., 2015). Overall, the presence of FR in each indoor environment depends on the materials present in each environment and the FR formulations used in each place/country, which is very much associated with the ongoing regulations regarding the type, amount and use of FR in finished materials.

\section{Conclusions}

This study investigated the presence of three FR families (PBDEs, NBFRs, OPFRs) in dust from homes, schools, theatres, a university and a research institute from Barcelona, Spain. Among studied compounds, OPFRs were present at the highest concentration, followed by PBDEs and finally NBFRs. The simultaneous presence of different FR families in dust from all studied indoor environments indicated that PBDE prohibition in Europe is resulting in the use of alternative substances. Among PBDEs, the predominant detection of BDE-209 in dust is a result of the enduring presence of materials containing this compound in comparison to for penta- and octa-BDE formulations. However, DBDPE was present is dust where EEE is used, which suggest that decaBDE formulations are being replaced by other compounds. The levels and profile of FRs in the different places were consistent with the materials deployed or present in each environment, where theatres followed by homes presented the highest concentrations and schools presented the lowest levels. The sources and patterns of FRs in indoor dust of each microenvironment was assessed using principal component analysis which permitted to determine a general contamination by OPFRs and a specific presence of BDE-209 and NBFRs mainly in homes and theatres. FRs in indoor dust contributes to human exposure due to inhalation or dermal contact.

\section{Funding sources}

This study was financed by the Ministry of Education and Innovation of Spain, project CTM2008-03263/TECNO.

\section{Acknowledgements}

This study has been performed thanks to the support, help and interests of various schools, specifically Betània-Patmos who provided data on their specific characteristics to determine the source of FR. Dr. FJ Santos is acknowledged for providing the dust sample from the UB and Gabino Bolivar and Núria Montaner for providing dust sample from their houses. This study was financed by the Ministry of Education and Innovation of Spain, project CTM200803263/TECNO. Joyce Cristale acknowledges a FPI grant from the same Ministry (BES-2009-016460).

\section{References}

Abdallah, M.A.E., Covaci, A., 2014. Organophosphate flame retardants in indoor dust from Egypt: implications for human exposure. Environ. Sci. Technol. 48, $4782-4789$.

Abdallah, M.A.E., Pawar, G., Harrad, S., 2015. Evaluation of in vitro vs. in vivo methods for assessment of dermal absorption of organic flame retardants: a review. Environ. Int. 74, 13-22.

Alaee, M., Arias, P., Sjödin, A., Bergman, Å., 2003. An overview of commercially used brominated flame retardants, their applications, their use patterns in different countries/regions and possible modes of release. Environ. Int. 29, 683-689.

Ali, N., Dirtu, A.C., Eede, N.V.D., Goosey, E., Harrad, S., Neels, H., t Mannetje, A., Coakley, J., Douwes, J., Covaci, A., 2012. Occurrence of alternative flame retardants in indoor dust from New Zealand: indoor sources and human exposure assessment. Chemosphere 88, 1276-1282.

Allen, J.G., McClean, M.D., Stapleton, H.M., Webster, T.F., 2008. Critical factors in assessing exposure to PBDEs via house dust. Environ. Int. 34, 1085-1091.

Araki, A., Saito, I., Kanazawa, A., Morimoto, K., Nakayama, K., Shibata, E., Tanaka, M., Takigawa, T., Yoshimura, T., Chikara, H., Saijo, Y., Kishi, R., 2014. Phosphorus flame retardants in indoor dust and their relation to asthma and allergies of inhabitants. Indoor Air 24, 3-15.

Bennett, D.H., Moran, R.E., Wu, X.M., Tulve, N.S., Clifton, M.S., Colón, M., Weathers, W., Sjödin, A., Jones, R., Hertz-Picciotto, I., 2015. Polybrominated diphenyl ether (PBDE) concentrations and resulting exposure in homes in California: relationships among passive air, surface wipe and dust concentrations, and temporal variability. Indoor Air 25, 220-229.

Betts, K., 2009. Glut of data on "new" flame retardant documents its presence all over the world. Environ. Sci. Technol. 43, 236-237.

Björklund, J.A., Sellström, U., de Wit, C.A., Aune, M., Lignell, S., Darnerud, P.O., 2012. Comparisons of polybrominated diphenyl ether and hexabromocyclododecane concentrations in dust collected with two sampling methods and matched breast milk samples. Indoor Air 22, 279-288.

BSI - British Standards Institution, 1982. Fire Tests for Furniture, methods of test for the ignitability of upholstered composites for seating by flaming sources. British Standards Institution.

Cao, Z., Xu, F., Covaci, A., Wu, M., Wang, H., Yu, G., Wang, B., Deng, S., Huang, J., Wang, X., 2014. Distribution patterns of brominated, chlorinated, and phosphorus flame retardants with particle size in indoor and outdoor dust and implications for human exposure. Environ. Sci. Technol. 48, 8839-8846.

Cequier, E., Ionas, A.C., Covaci, A., Marcé, R.M., Becher, G., Thomsen, C., 2014. Occurrence of a broad range of legacy and emerging flame retardants in indoor environments in Norway. Environ. Sci. Technol. 48, 6827-6835.

Colt, J.S., Zahm, S.H., Camann, D.E., Hartge, P., 1998. Comparison of pesticides and other compounds in carpet dust samples collected from used vacuum cleaner bags and from a high-volume surface sampler. Environ. Health Perspect. 106, $721-724$.

Covaci, A., Harrad, S., Abdallah, M.A.E., Ali, N., Law, R.J., Herzke, D., de Wit, C.A., 2011. Novel brominated flame retardants: a review of their analysis, environmental fate and behaviour. Environ. Int. 37, 532-556.

Cristale, J., Lacorte, S., 2013. Development and validation of a multiresidue method for the analysis of polybrominated diphenyl ethers, new brominated and organophosphorus flame retardants in sediment, sludge and dust. J. Chromatogr. A 1305, 267-275.

Cristale, J., Quintana, J., Chaler, R., Ventura, F., Lacorte, S., 2012. Gas chromatography/mass spectrometry comprehensive analysis of organophosphorus, brominated flame retardants, by-products and formulation intermediates in water. J. Chromatogr. A 1241, 1-12.

Darnerud, P.O., 2003. Toxic effects of brominated flame retardants in man and in wildlife. Environ. Int. 29, 841-853.

ECHA - European Chemicals Agency, 2008. European Chemicals Agency. TRIS (2chloroethyl) phosphate, TCEP. Summary Risk Assessment Report.

ECJ - European Court of Justice, 2008. Case C-14/06 (2008-04-01).

EFRA - European Flame Retardants Association, 2005. International Fire Statistics and the Potential Benefits of Fire Counter-Measures. Available in $\langle$ http://www. bsef.com/uploads/MediaRoom/documents/internationalfirestatistics2005-1. 00.pdf $)$. (accessed 21.12.2015).

EURAR - European Union Risk Assessment Report, 2008a. Tris(2-chloro-1-methylethyl) Phosphate (TCPP) Risk Assessment.

EURAR - European Union Risk Assessment Report, 2008b. Tris[2-chloro-1-(chloromethyl)ethyl] phosphate (TDCP) Risk Assessment. European Union Risk Assessment Report.

Ezechiáš, M., Covino, S., Cajthaml, T., 2014. Ecotoxicity and biodegradability of new brominated flame retardants: a review. Ecotoxicol. Environ. Saf. 110, 153-167.

Farnham, I.M., Singh, A.K., Stetzenbach, K.J., Johannesson, K.H., 2002. Treatment of nondetects in multivariate analysis of groundwater geochemistry data. Chemom. Intell. Lab. Syst. 60, 265-281.

Fromme, H., Hilger, B., Kopp, E., Miserok, M., Völkel, W., 2014. Polybrominated diphenyl ethers (PBDEs), hexabromocyclododecane (HBCD) and "novel" brominated flame retardants in house dust in Germany. Environ. Int. 64, 61-68.

Hale, R.C., La Guardia, M.J., Harvey, E., Matt Mainor, T., 2002. Potential role of fire retardant-treated polyurethane foam as a source of brominated diphenyl ethers to the US environment. Chemosphere 46, 729-735.

Hassan, Y., Shoeib, T., 2015. Levels of polybrominated diphenyl ethers and novel flame retardants in microenvironment dust from Egypt: an assessment of human exposure. Sci. Total Environ. 505, 47-55.

He, C.T., Zheng, J., Qiao, L., Chen, S.J., Yang, J.Z., Yuan, J.G., Yang, Z.Y., Mai, B.X., 2015. Occurrence of organophosphorus flame retardants in indoor dust in multiple microenvironments of southern China and implications for human exposure. Chemosphere $133,47-52$.

Kim, J.W., Isobe, T., Sudaryanto, A., Malarvannan, G., Chang, K.H., Muto, M., Prudente, M., Tanabe, S., 2013. Organophosphorus flame retardants in house dust from the Philippines: occurrence and assessment of human exposure. Environ. Sci. Pollut. Res. 20, 812-822.

Liagkouridis, I., Cousins, I.T., Cousins, A.P., 2014. Emissions and fate of brominated flame retardants in the indoor environment: a critical review of modelling 
approaches. Sci. Total Environ. 491-492, 87-99.

Lim, Y.W., Kim, H.H., Lee, C.S., Shin, D.C., Chang, Y.S., Yang, J.Y., 2014. Exposure assessment and health risk of poly-brominated diphenyl ether (PBDE) flame retardants in the indoor environment of elementary school students in Korea. Sci. Total Environ. 470-471, 1376-1389.

Lyche, J.L., Rosseland, C., Berge, G., Polder, A., 2015. Human health risk associated with brominated flame-retardants (BFRs). Environ. Int. 74, 170-180.

Mizouchi, S., Ichiba, M., Takigami, H., Kajiwara, N., Takamuku, T., Miyajima, T., Kodama, H., Someya, T., Ueno, D., 2015. Exposure assessment of organophosphorus and organobromine flame retardants via indoor dust from elementary schools and domestic houses. Chemosphere 123, 17-25.

Newton, S., Sellström, U., De Wit, C.A., 2015. Emerging flame retardants, PBDEs, and HBCDDs in indoor and outdoor media in Stockholm, Sweden. Environ. Sci. Technol. 49, 2912-2920.

OJEC - Official Journal of the European Communities, 1995. Directive 95/28/EC of The European Parliament and of the Council of 24 of october of 1995 relating to the burning behavior of materials used in the interior construction of certain categories of motor vehicle.

OJEC - Official Journal of the European Communities, 2000. Commission Decision of 8 February 2000 implementing Council Directive 89/106/EEC as regards the classification of the reaction to fire performance of construction products.

OJEU - Official Journal of the European Union, 2003a. Directive 2002/95/EC of the European Parliament and of the Council of 27 January 2003 on the restriction of the use of certain hazardous substances in electrical and electronic equipment.

OJEU - Official Journal of the European Union, 2003b. Directive 2003/11/EC of the European Parliament and of the Council of 6 February 2003 amending for the 24th time Council Directive 76/769/EEC relating to restrictions on the marketing and use of certain dangerous substances and preparations (pentabromodiphenyl ether, octabromodiphenyl ether).

OJEU - Official Journal of the European Union, 2005. Commission Decision of 13 October 2005 amending for the purposes of adapting to the technical progress the Annex to Directive 2002/95/EC of the European Parliament and of the council on the restriction of the use of certain hazardous substances in electrical and electronic equipment.

Rauert, C., Lazarov, B., Harrad, S., Covaci, A., Stranger, M., 2014. A review of chamber experiments for determining specific emission rates and investigating migration pathways of flame retardants. Atmos. Environ. 82, 44-55.

SCHER - Scientific Committee on Health and Environmental Risks, 2012. Opinion on Tris(2-chloroethyl)Phosphate (TCEP) in Toys.

Schlummer, M., Gruber, L., Mäurer, A., Wolz, G., van Eldik, R., 2007. Characterisation of polymer fractions from waste electrical and electronic equipment (WEEE) and implications for waste management. Chemosphere 67, 1866-1876.

Schreder, E.D., La Guardia, M.J., 2014. Flame retardant transfers from U.S. households (dust and laundry wastewater) to the aquatic environment. Environ. Sci. Technol. 48, 11575-11583.

Stapleton, H.M., Allen, J.G., Kelly, S.M., Konstantinov, A., Klosterhaus, S., Watkins, D. McClean, M.D., Webster, T.F., 2008. Alternate and new brominated flame retardants detected in U.S. house dust. Environ. Sci. Technol. 42, 6910-6916.

SpecialChem, 2013. Flame Retardants Center. In: 〈http://www.specialchem4poly mers.com/tc/flame-retardants/index.aspx $\rangle$. (accessed 06.05.2013).

Stapleton, H.M., Klosterhaus, S., Eagle, S., Fuh, J., Meeker, J.D., Blum, A., Webster, T.F. 2009. Detection of organophosphate flame retardants in furniture foam and $U$. S. house dust. Environ. Sci. Technol. 43, 7490-7495.

Tajima, S., Araki, A., Kawai, T., Tsuboi, T., Ait Bamai, Y., Yoshioka, E., Kanazawa, A., Cong, S., Kishi, R., 2014. Detection and intake assessment of organophosphate flame retardants in house dust in Japanese dwellings. Sci. Total Environ. 478, 190-199.

Van den Eede, N., Dirtu, A.C., Neels, H., Covaci, A., 2011. Analytical developments and preliminary assessment of human exposure to organophosphate flame retardants from indoor dust. Environ. Int. 37, 454-461.

van der Veen, I., de Boer, J., 2012. Phosphorus flame retardants: properties, production, environmental occurrence, toxicity and analysis. Chemosphere 88, 1119-1153.

Vonderheide, A.P., Mueller, K.E., Meija, J., Welsh, G.L., 2008. Polybrominated diphenyl ethers: causes for concern and knowledge gaps regarding environmental distribution, fate and toxicity. Sci. Total Environ. 400, 425-436.

WHO - World Health Organization, 1994. Brominated diphenyl ethers. Environ. Health Criteria, 162.

WHO - World Health Organization, 1998. Flame retardants: tris(chloropropyl) phosphate and tris(2-chloroethyl) phosphate. Environ. Health Criteria, 209.

WHO - World Health Organization, 2000. Flame retardants: tris(2-butoxyethyl) phosphate, tris(2-ethylhexyl) phosphate and tetrakis(hydroxymethyl) phosphonium salts. Environ. Health Criteria, 218.

Wold, S., Esbensen, K., Geladi, P., 1987. Principal component analysis. Chemom. Intell. Lab. Syst. 2, 37-52.

WSU, 2006. Washington State polybrominated diphenyl ether (PBDE) chemical action plan: Final plan. Report number 05-07-048. Washington State University, Department of Ecology: Olympia, WA.

Zheng, X., Xu, F., Chen, K., Zeng, Y., Luo, X., Chen, S., Mai, B., Covaci, A., 2015. Flame retardants and organochlorines in indoor dust from several e-waste recycling sites in South China: composition variations and implications for human exposure. Environ. Int. 78, 1-7.

Zhu, N.Z., Liu, L.Y., Ma, W.L., Li, W.L., Song, W.W., Oi, H., Li, Y.F., 2015. Polybrominated diphenyl ethers (PBDEs) in the indoor dust in China: levels, spatial distribution and human exposure. Ecotoxicol. Environ. Saf. 111, 1-8. 